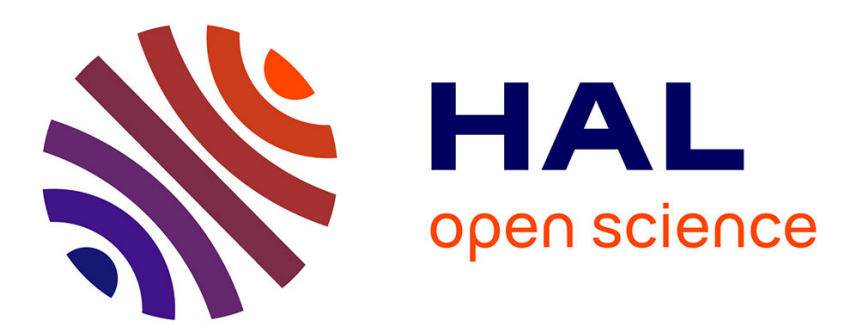

\title{
From tectons to luminescent supramolecular ionic liquid crystals
}

Pierre Dechambenoit, Sylvie Ferlay, Bertrand Donnio, Daniel Guillon, Mir

Wais Hosseini

\section{- To cite this version:}

Pierre Dechambenoit, Sylvie Ferlay, Bertrand Donnio, Daniel Guillon, Mir Wais Hosseini. From tectons to luminescent supramolecular ionic liquid crystals. Chemical Communications, 2011, 47 (2), pp.734-736. 10.1039/C0CC03970E . hal-02301256

\section{HAL Id: hal-02301256 \\ https://hal.science/hal-02301256}

Submitted on 27 Nov 2020

HAL is a multi-disciplinary open access archive for the deposit and dissemination of scientific research documents, whether they are published or not. The documents may come from teaching and research institutions in France or abroad, or from public or private research centers.
L'archive ouverte pluridisciplinaire HAL, est destinée au dépôt et à la diffusion de documents scientifiques de niveau recherche, publiés ou non, émanant des établissements d'enseignement et de recherche français ou étrangers, des laboratoires publics ou privés. 


\title{
From tectons to luminescent supramolecular ionic liquid crystals
}

\author{
Pierre Dechambenoit $^{a, c}$, Sylvie Ferlay ${ }^{a^{*}}$, Bertrand Donnio ${ }^{b}$, Daniel Guillon ${ }^{\mathrm{b}}$ and Mir Wais Hosseini ${ }^{\mathbf{a}^{*}}$ \\ Received (in XXX, XXX) Xth $X X X X X X X X X 200 X$, Accepted Xth $X X X X X X X X X 200 X$ \\ First published on the web $X$ th $X X X X X X X X X 200 X$ \\ s DOI: 10.1039/b000000x
}

\begin{abstract}
New phosphorescent and room-temperature liquid-crystalline materials were obtained by combining dicyanometallate anions with dicationic bisamidinium based tectons bearing four peripheral lipophilic pyrogallate moieties.
\end{abstract}

10 Liquid crystals (LCs) constitute a class of soft materials, combining order with fluidity within various types of mobile and low-dimensional periodic structures. ${ }^{1}$ Their dynamic nature, function-integration and stimuli-responsiveness abilities render them interesting for technological 15 applications. $^{2}$ However, the control of self-assembling and self-organizing processes from functional nano-segregated structures to micrometric scale by molecular engineering still remains a challenge. Over the last two decades, the supramolecular approach, based on molecular recognition 20 events, ${ }^{3}$ has been considered ${ }^{4}$ for generating novel LC assemblies integrating new functions. The majority of reported supramolecular LCs is mainly based on the use of non-ionic ${ }^{5}$ or ionic ${ }^{6} \mathrm{H}$-bonding.

Functional mesophases displaying emissive properties are 25 mostly achieved using either purely organic luminophores ${ }^{7}$ or transition metal $^{8}$ and lanthanide ${ }^{9}$ complexes. Hereafter, we report on new phosphorescent LC materials elaborated by molecular tectonic, an approach until now sparingly used in this area.

30 networks (Fig. 1a). ${ }^{15}$ The formation of the latter results from both electrostatic charge-charge interactions and directional $\mathrm{H}$ bonds between the acidic $\mathrm{H}$ atoms of $\mathbf{1}^{2+}$ and $\mathrm{N}$ atoms of $\mathrm{CN}$ ligands of $\mathrm{M}(\mathrm{CN})_{2}{ }^{-}$. Furthermore, analogues of $\mathbf{1}^{2+}$ bearing 50 alkyl chains $\mathbf{2}^{2+}$ (propyl ${ }^{16}$, hexyl or dodecyl groups) were found to behave in a similar fashion, demonstrating that the presence of alkyl substituents at these two positions do not alter the recognition pattern observed between the dication and $\mathrm{M}(\mathrm{CN})_{2}{ }^{-}$(Fig. 1a). ${ }^{17}$

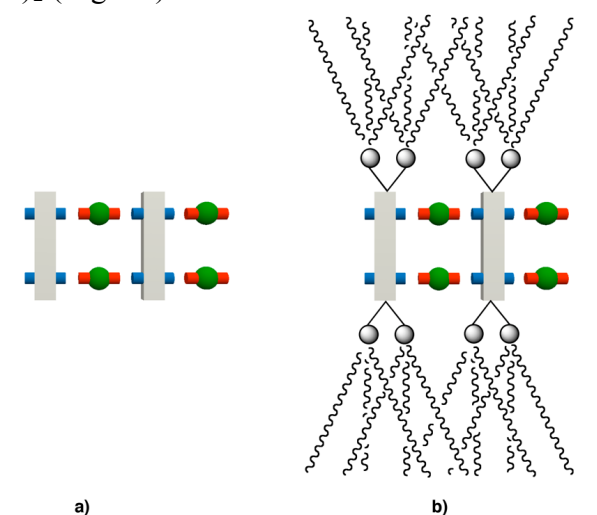

55

b)

Figure 1: Schematic representation of 1D H-bonded networks (ladderlike type) formed upon combination of the dicationic organic tecton $\mathbf{1}^{2+}$ (a) or lipophilic $3^{2+}$ (b) with dicyanometallates.

In order to avoid crystallization and to induce the formation 60 of mesophases, while maintaining the formation of $1 \mathrm{D}$ networks (Fig. 1b), the dicationic tecton $\mathbf{3}^{2+}$ bearing four peripheral lipophilic pyrogallate units (Scheme 1) was considered as an appropriate unit to be combined with $\mathrm{M}(\mathrm{CN})_{2}{ }^{-}$.

${ }_{65}$ As stated above, the design of $\mathbf{3}^{+}$is based on the tetra H-bonddonor-unit bisamidinium central core bearing four mesogenic 3,4,5-trisalkoxybenzyl groups offering 12 flexible chains disposed in a symmetrical fashion. The phenyl spacer connecting the two cyclic amidinium moieties was chosen 70 because not only it increases considerably the stability of the tecton towards hydrolysis but in addition it imposes the required distances between the two acidic $\mathrm{H}$ atoms on each face of the tecton and thus a distance of $c a$ 4.0-4.2 $\AA$ between the two metal centers ( $\mathrm{Ag}$ or $\mathrm{Au}$ ) and furthermore enhances 75 that axial anisotropy of the system. This rather short M-M distance of $c a 4.0-4.2 \AA$ leads to metallophilic interactions ${ }^{18}$ between adjacent metallic centers ( $\mathrm{Ag}$ or $\mathrm{Au})$.

The interconnection of the mesogenic unit to the cyclic amidinium moieties was achieved using positions 1 and 4 of 80 the phenyl group and the position 3 on the cyclic amidinium moiety. The junction between the rigid and flexible units was 
an ether group. As for the length of the alkyl chain, the dodecyl fragment was chosen.

The detailed synthetic strategy as well as preparative procedures for $\left[3^{2+}\right]\left[\mathrm{Cl}^{-}\right]_{2}$ and $\left[3^{2+}\right]\left[\mathrm{Ag}(\mathrm{CN})_{2}{ }^{-}\right]_{2}$ are given in 5 ESI.

The mesomorphic behaviour of $\left[3^{2+}\right]\left[\mathrm{X}^{-}\right]_{2} \quad(\mathrm{X}=\mathrm{Cl}$ or $\left.\mathrm{Ag}(\mathrm{CN})_{2}\right)$ was analyzed by polarized optical microscopy (POM), differential scanning calorimetry (DSC, figure $\mathrm{S} 1$ for $\left[3^{2+}\right]\left[\mathrm{Cl}^{-}\right]_{2}$ and $\mathrm{S} 2$ for $\left[3^{2+}\right]\left[\mathrm{Ag}(\mathrm{CN})_{2}{ }^{-}\right]_{2}$ in ESI) and small10 angle X-ray scattering (SAXS). As deduced by POM and DSC, $\left[3^{2+}\right]\left[\mathrm{Cl}^{-}\right]_{2}$ and $\left[3^{2+}\right]\left[\mathrm{Ag}(\mathrm{CN})_{2}^{-}\right]_{2}$ self-organize into fluid liquid crystalline mesophases from RT to $80{ }^{\circ} \mathrm{C}$ and $110{ }^{\circ} \mathrm{C}$, respectively (for the latter compound, the glass transition temperature $(\mathrm{Tg})$ was detected during the first heating at 64 $15{ }^{\circ} \mathrm{C}$, but not on subsequent cycles). As expected, the large number of divergent chains on the cations are responsible for the low melting-temperature behaviour. ${ }^{19}$ In both cases, the mesophases optical textures were birefringent and homogeneous but not sufficiently characteristic, prohibiting 20 definitive mesophase assignments.

Temperature-dependent SAXS experiments confirmed and allowed LC phases' symmetry identification (Table 1). Both appeared as disordered mesophases as shown by the rather strong and diffuse signal in the wide-angle region (at around ${ }_{25} 4.5-4.6 \AA$ ) reflecting the liquid-like state of the molten alkyl chains. For $\left[3^{2+}\right]\left[\mathrm{Cl}^{-}\right]_{2}$, in the low angle region, several sharp and intense reflections are observed indicating the presence of 2D columnar arrangements, as shown in figure S3 (see ESI). At $40{ }^{\circ} \mathrm{C}$, up to 8 sharp reflections were observed. Their 30 indexation satisfied the conditions for the non-centered rectangular $p 2 g g$ planar group $\left(\mathrm{Col}_{\mathrm{r}}\right)$ (figure $\left.\mathrm{S} 3, \mathrm{ESI}\right)$.

For $\left[3^{2+}\right]\left[\mathrm{Ag}(\mathrm{CN})_{2}^{-}\right]_{2}$, at $40^{\circ} \mathrm{C}$, the X-ray pattern was composed of two sharp signals, shown in figure 2 , with reciprocal $d$-spacing in the ratio $1: \sqrt{3}$. This is compatible with 35 the assignment of the two peaks as (10) and (11) reflections of the $2 \mathrm{D}$ hexagonal lattice with $\mathrm{p} 6 \mathrm{~mm}$ planar group $\left(\mathrm{Col}_{\mathrm{h}}\right.$ phase). (figure 2)

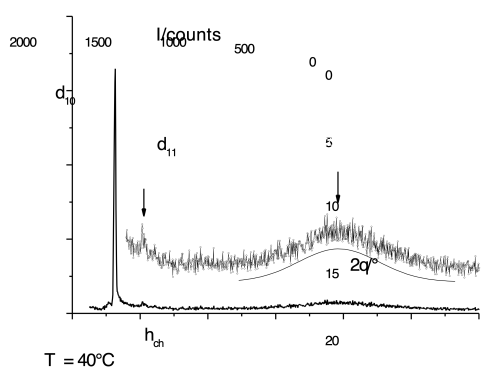

Figure 2: Small-angle XRD diffraction pattern and peaks 40 indexation for $\left[3^{2+}\right]\left[\mathrm{AgCN}_{2}^{-}\right]_{2}$, recorded at $313 \mathrm{~K}$, second heating (Gaussian fit of the diffuse scattering halo).

Considering a mean density of $\mathrm{ca} 1 \mathrm{gcm}^{-3}$ for both salts in their respective phase, about one molecular equivalent $\left(\left[3^{2+}\right]\left[\mathrm{Cl}_{2}{ }^{-}\right]_{2}\right)$ or one elementary repeat unit $\left(\left[3^{2+}\right]\left[\mathrm{Ag}(\mathrm{CN})_{2}{ }^{-}\right]_{2}\right)$ 45 occupies the elementary columnar slice 4.5-4.6 $\AA$-thick (Table 1). The specific Ag-Ag distances (in the $20^{\circ}<2 \quad 25^{\circ}$ range) cannot be detected by X-Ray diffraction, due to the presence of the diffuse and intense signal corresponding to the molten chains.
50 Table 1: Mesomorphic behaviour and mesophase structural data for $\left[3^{2+}\right]\left[\mathrm{X}^{-}\right]_{2}$. Temperatures in ${ }^{\circ} \mathrm{C}, \quad \mathrm{H}$ in $\mathrm{kJmol}^{-1}$, and $\mathrm{Cp}$ in $\mathrm{Jmol}^{-1} \mathrm{~K}^{-1}$ (glass transition).

\begin{tabular}{|c|c|c|c|c|c|c|}
\hline $\begin{array}{l}\text { Mesomophic } \\
\text { behaviour }^{[\mathrm{a}]}\end{array}$ & $d_{\exp } / \AA^{[\mathrm{b}}$ & $\mathbf{I}^{[\mathrm{c}]}$ & $\begin{array}{l}h k] \\
{[\mathrm{d}]}\end{array}$ & $d_{\text {theo }} / \AA^{[\mathrm{b}]}$ & Parameters $^{[\mathrm{e}]}$ & $\begin{array}{c}h / \AA^{[\mathrm{e}]}, \\
N\end{array}$ \\
\hline \multirow[t]{2}{*}[3^{2+}]{$\left[\mathrm{Cl}^{-}\right]_{2}$} & 34.1 & VS (sh) & 11 & 34.1 & $\mathrm{~T}=40^{\circ} \mathrm{C}$ & $\mathrm{V}_{\mathrm{mol}}=$ \\
\hline & 30.45 & $\mathrm{M}(\mathrm{sh})$ & 20 & 30.45 & Colr-p2gg & 4800 \\
\hline $\mathrm{Cr}-12(42.5)$ & 19.75 & M (sh) & 12 & 19.5 & $a=60.9 \AA$ & $\AA^{3}$ \\
\hline Colr-p2gg 80 & 17.05 & M (sh) & 22 & 17.05 & $b=41.15 \AA$ & $N \sim 1$ \\
\hline \multirow[t]{5}{*}{ (3.3) I } & 15.6 & W (sh) & 40 & 15.22 & $S=2506 \AA^{2}$ & \\
\hline & 11.26 & W (sh) & 33 & 11.37 & & \\
\hline & 9.5 & M (sh) & 24 & 9.75 & & \\
\hline & 8.55 & M (sh) & 44 & 8.52 & & \\
\hline & 4.5 & VS (br) & & $\mathrm{h}_{\mathrm{ch}}$ & & \\
\hline \multirow[t]{2}{*}[3^{2+}]{$\left[\mathrm{Ag}(\mathrm{CN})_{2}{ }^{-}\right]_{2}$} & 29.87 & VS (sh) & 10 & 29.85 & $\mathrm{~T}=40^{\circ} \mathrm{C}$ & $\mathrm{V}_{\mathrm{mol}}=$ \\
\hline & 17.22 & W (sh) & 11 & 17.23 & $\mathrm{Col}_{\mathrm{h}}-p 6 m m$ & 4950 \\
\hline $\mathrm{g}(2.7) 64 \mathrm{Col}_{\mathrm{h}}$ & 4.6 & VS (br) & & $\mathrm{h}_{\mathrm{ch}}$ & $a=34.46 \AA$ & $\AA^{3}$ \\
\hline $110(-)^{[\mathrm{f}]} \mathrm{I}$ & & & & & $S=1029 \AA^{2}$ & $N \sim 1$ \\
\hline
\end{tabular}

Abbreviations: ${ }^{[a]} \mathrm{Col}_{\mathrm{h}}=$ hexagonal columnar phase; $\mathrm{Col}_{\mathrm{r}}=$ rectangular columnar phase; $\mathrm{Cr}=$ crystalline phase; $\mathrm{g}=$ glass; $\mathrm{I}=$ isotropic liquid. ${ }_{55}{ }^{[\mathrm{b}]} d_{\exp }$ and $d_{\text {theo }}$ are the experimentally measured and theoretical diffraction spacings. The distances are given in $\AA .{ }^{[c]}$ Intensity of the reflections: VS: very strong, M: medium, W: weak; br and sh stand for broad and sharp reflections, respectively. ${ }^{[\mathrm{d}]}[h k]$ are the Miller indices of the reflections ${ }^{20}$. ${ }^{\left[{ }^{[}\right]}$Mesophases parameters $a, b, S$, are deduced from the following 60 mathematical expressions. For $\mathrm{Colh}$, the lattice parameter $a=$ $2\left[{ }_{h k} d_{h k} \cdot\left(h^{2}+k^{2}+h k\right)^{1 / 2}\right] / \sqrt{3} N_{h k}$ where $N_{h k}$ is the number of $h k$ reflections, and the lattice area (i.e. columnar cross-section) $S=a^{2} 3^{1 / 2} / 2$. For Colr, $<\mathrm{d}_{h k}>=1 /\left[\left(h^{2} / a^{2}+k^{2} / b^{2}\right)^{1 / 2}\right]$, the lattice area $S=a \times b$ (columnar crosssections $=S / 2$ ). $N$ is the number of molecules (or molecular equivalents): ${ }_{65} N=\mathrm{h}_{\text {ch. }} S / \mathrm{V}_{\text {mol }}{ }^{21}$ where $S$ is the columnar cross-section, $V_{\text {mol }}$ is the molecular volume (estimated with a density close to 1 ) and $h_{c h}$ the average thickness of the molecule for repeating stacking distance along the column (i.e. the diffuse scattering corresponding to the molten aliphatic chains). ${ }^{[\mathrm{ff}}$ Transition not detected by DSC, but by POM and 70 XRD.

As previously observed for $\left[\mathbf{1}^{2+}\right]\left[\mathrm{Ag}(\mathrm{CN})_{2}{ }^{-}\right]_{2}$ in the crystalline phase, ${ }^{15}$ the mesophase generated by $\left[3^{2+}\right]\left[\mathrm{Ag}(\mathrm{CN})_{2}{ }^{-}\right]_{2}$ also displays luminescence (Fig. 3). Indeed, excitation of $\left[3^{2+}\right]\left[\mathrm{Ag}(\mathrm{CN})_{2}{ }^{-}\right]_{2}$ at $380 \mathrm{~nm}$ leads to blue luminescence at 430 $75 \mathrm{~nm}$. In contrast, no emission is observed for $\left[3^{2+}\right]\left[\mathrm{Cl}^{-}\right]_{2}$ implying probably that the luminescence is related to $\mathrm{Ag}-\mathrm{Ag}$ interactions. $^{22}$ Moreover, the mesogenic structural changes between $\left[3^{2+}\right]\left[\mathrm{Cl}^{-}\right]_{2}$ and $\left[3^{2+}\right]\left[\mathrm{Ag}(\mathrm{CN})_{2}^{-}\right]_{2}$ clearly indicates a different packing for the latter, involving $\mathrm{H}$ bonds and 80 formation of the already observed recognition mode between cations and anions, leading to a $1 \mathrm{D}$ network. ${ }^{15}$

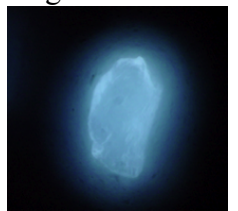

Figure 3: Photomicrograph showing the blue luminescence of the $\left[\mathbf{3}^{2+}\right]\left[\mathrm{Ag}(\mathrm{CN}) 2^{-}\right]_{2}$ mesophase.

${ }_{85}$ For $\left[\mathbf{3}^{2+}\right]\left[\mathrm{Ag}(\mathrm{CN})_{2}{ }^{-}\right]_{2}$, based on X-ray and luminescence data, the following model for the $\mathrm{Col}_{\mathrm{h}}$ phase may be proposed: disks made of a single organic mesogenic tecton $3^{2+}$ are interconnected by $\mathrm{Ag}(\mathrm{CN})_{2}{ }^{-}$through both $\mathrm{H}$-bonds between acidic $\mathrm{H}$ atoms of $\mathbf{3}^{2+}$ and $\mathrm{CN}$ groups of the cyanometallate 90 and electrostatic interactions forming thus neutral 1D laddertype networks (Fig. 1b). The latter, surrounded by flexible alkyl chains (Fig. 4), pack into a 2D hexagonal lattice where the relative orientations (ie defined by the normal axis of the 
1-D network) of the molecular ladders are not necessarily correlated with neighbouring columns of the hexagonal network. This model also agrees with the enhanced thermal stability observed for $\left[3^{2+}\right]\left[\mathrm{Ag}(\mathrm{CN})_{2}{ }^{-}\right]_{2}$ with respect to ${ }_{5}\left[\mathbf{3}^{2+}\right]\left[\mathrm{Cl}^{-}\right]_{2}$.

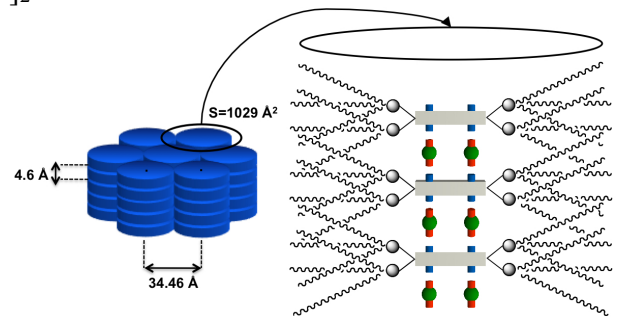

Figure 4: Proposed columnar model based on the interconnection of disks composed of $3^{2+}$ by $\mathrm{Ag}(\mathrm{CN})_{2}$.

\section{Conclusions}

10 The combination of the mesogenic dicationic tecton $3^{2+}$, bearing 12 divergently oriented $\mathrm{C} 12$ aliphatic chains, with $\mathrm{Ag}(\mathrm{CN})_{2}{ }^{-}$leads to the formation of a supramolecular 1D charge-assisted H-bonded network displaying columnar mesophase properties in a wide temperature range. The

15 columnar mesophase might result from interconnections of disks composed of $\mathbf{3}^{2+}$ by $\mathrm{Ag}(\mathrm{CN})_{2}{ }^{-}$through both H-bonds and electrostatic interactions. The imposed rather short $\mathrm{Ag}-\mathrm{Ag}$ distance through the design of the organic tecton $\mathbf{3}^{2+}$ is probably responsible for the observed blue luminescence of 20 the mesophase. The extension of this approach to other organic mesogens and metal complexes is currently under investigation.

\section{ACKNOWLEDGMENT}

${ }_{25}$ Université de Strasbourg, Institut Universitaire de France, CNRS and the Ministry of Education and Research are acknowledged for financial support and for a scholarship to P. D.

\section{Notes and references}

${ }_{30}{ }^{a}$ Laboratoire de Chimie de Coordination Organique, UMR CNRS 7140, Université de Strasbourg, Institut Le Bel, 4, rue Blaise Pascal, CS 90032 67081 STRASBOURG Cedex, France

${ }^{b}$ IPCMS, UMR 7504, CNRS-Université de Strasbourg, 23 rue du Loess, BP 43, F-67034 STRASBOURG Cedex 2, France

$35{ }^{c}$ Present adress CRPP, Centre de Recherche Paul Pascal, 115 Avenue Schweitzer 33600 PESSAC

$\dagger$ Electronic Supplementary Information (ESI) available: Complete synthesis of $\left[3^{2+}\right]\left[\mathrm{Cl}^{-}\right]_{2}$ and $\left[3^{2+}\right]\left[\mathrm{Ag}(\mathrm{CN})_{2}{ }^{-}\right]$, DSC measurements and SA$\mathrm{XRD}$ for $\left[3^{2+}\right]\left[\mathrm{Cl}^{-}\right]_{2}$. See DOI: $10.1039 / \mathrm{b} 000000 \mathrm{x} /$

(1) Handbook of Liquid Crystals; D. Demus, J. W. Goodby, G. W. Gray, H.-W. Spiess, V. Vill, Eds., 1998, Wiley-VCH, Weinheim.

(2) (a) M. O'Neill and S. M. Kelly, Adv. Mater. 2003, 15, 1135; (b) S. Sergeyev, W. Pisula and Y. H. Geerts, Chem. Soc. Rev., 2007, 36, 1902.

(3) (a) M. J. Brienne, J. Galard, J.-M. Lehn and J. Stibor, Chem. Commun., 1989, 1868; (b) T. Kato and J. M. J. Fréchet, J. Am. Chem. Soc. 1989, 111, 8533.

(4) T. Kato, N. Mizoshita and K. Kishimoto, Angew. Chem. Int. Ed. 2006, 45,38 .
(5) (a) J. Malthête, A. M. Levelut and L. Liebert, Adv. Mater., 1992, 4 , 37; (b) R. Deschenaux, F. Monnet, E. Serrano, F. Turpin and A.-M. Levelut, Helv. Chim. Acta, 1998, 81, 2072; (c) C. M. Paleos and D. Tsiourvas, Liq. Cryst. 2001, 28, 1127; (d) S. Jin, Y. Ma, S. C. Zimmerman and S. Z. D. Cheng, Chem. Mater., 2004, 16, 2975; (e) S. Coco, E. Espinet, P. Espinet and I. Palape, Dalton Trans., 2007, 3267.

(6) (a) K. Binnemans, Chem. Rev. 2005, 105, 4148; (b) A. Kraft, A. Reichert and R. Kleppinger, Chem. Commun., 2000, 1015; (c) M. W. Hosseini, D. Tsiourvas, J.-M. Planeix, Z. Sideratou, N. Thomas and C. M. Paleos, Collec. Czech. Chem. Comm., 2004, 1161.

(7) (a) J. F. Hulvat, M. Sofos, K. Tajima and S. I. Stupp, J. Am. Chem. Soc., 2005, 127, 366; (b) F. Camerel, L. Bonardi, G. Ulrich, L. Charbonnière, B. Donnio, C. Bourgogne, D. Guillon, P. Retailleau and R. Ziessel, Chem. Mater., 2006, 18, 5009.

(8) (a) F. Camerel, R. Ziessel, B. Donnio, C. Bourgogne, D. Guillon, M. Schmutz, C. Iacovita and J.-P. Bucher, Angew. Chem. Int. Ed., 2007, 46, 2659; (b) M. Ghedini, D. Pucci, A. Crispini, A. Bellusci, M. La Deda, I. Aiello and T. Pugliese, Inorg. Chem. Commun., 2007, 10, 243; (c) E. Cavero, S. Uriel, P. Romero, J.-L. Serrano and R. Gimenez, J. Am. Chem. Soc. 2007, 129, 11608; (d) V. N. Kozhevnikov, B. Donnio and D. W. Bruce, Angew. Chem. Int. Ed., 2008, 48, 6286.

(9) (a) E.Terazzi, S. Torelli, G. Bernardinelli, J.-P. Rivera, J.-M. Benech, C. Bourgogne, B. Donnio, D. Guillon, D. Imbert, J.-C. G. Bünzli, A. Pinto, D. Jeannerat and C. Piguet, J. Am. Chem. Soc., 2005, 127, 888. (b) K. Binnemans, J. Mater. Chem., 2009, 19, 448.

(10) (a) M. Simard, D. Su and J. D. Wuest, J. Am. Chem. Soc., 1991, 113, 4696; (b) S. Mann, Nature, 1993, 365, 499; (c) M. W. Hosseini, Acc. Chem. Res., 2005, 38, 313.

(11) (a) M. Surin, P. Samori, A. Jouaiti, N. Kyritsakas and M. W. Hosseini, Angew Chem. Int. Ed., 2006, 46, 245; (b) A. Ciesielski, L. Piot, P. Samori, A. Jouaiti and M. W. Hosseini, Adv. Mat., 2009, 21, 1131.

(12) (a) K. T. Holman, A. M. Pivovar, J. A. Swift and M. D.Ward, Acc. Chem. Res., 2001, 34, 107; (b) M. W. Hosseini, Coord. Chem. Rev., 2003, 240, 157.

(13) (a) S. Ferlay, O. Félix, M. W. Hosseini, J.-M. Planeix and N. Kyritsakas, Chem. Commun, 2002, 702; (b) P. Dechambenoit, S. Ferlay, M. W. Hosseini and N. Kyritsakas, J. Am. Chem. Soc., 2008, 130, 17106.

(14) O. Félix, M. W. Hosseini, A. De Cian and J. Fischer, New J. Chem., 1997, 21, 285.

(15) C. Paraschiv, S. Ferlay, M. W. Hosseini, V. Bulach and J-M. Planeix, Chem. Commun., 2004, 2270.

(16) P. Dechambenoit, S. Ferlay, M. W. Hosseini, J.-M. Planeix and N. Kyritsakas, New. J. Chem., 2006, 30, 1403.

(17) P. Dechambenoit, S. Ferlay, M. W. Hosseini and N. Kyritsakas submitted.

(18) (a) H. Schmidbaur, Chem. Soc. Rev., 1995, 24, 391; (b) P. Pyykkö, Chem. Rev., 1997, 97, 597.

(19) A. Escande, L. Guénée, H. Nozary, G. Bernardinelli, F. Gumy, A. Aebischer, J.-C. G. Bünzli, B. Donnio, D. Guillon and C. Piguet, Chem. Eur. J., 2007, 13, 8696.

(20) (a) International Tables for Crystallography, Vol. A, 4th ed (Ed.: Hahn, T.), The International Union of Crystallography, 1995, Kluwer Academic, Dordrecht, The Netherlands; (b) C. Hammond In The Basics of Crystallography and Diffraction, 2nd ed., 2001, IUCr, Oxford Science Publications, Oxford.

(21) (a) F. Morale, R. W. Date, D. Guillon, D. W. Bruce, R. L. Finn, C. Wilson, A. J. Blake, M. Schröder and B. Donnio, Chem. Eur. J., 2003, 9, 2484; (b) B. Donnio, B. Heinrich, H. Allouchi, J. Kain, S. Diele, D. Guillon and D. W. Bruce, J. Am. Chem. Soc., 2004, 126, 15258. (c) R. Ziessel, F. Camerel and B. Donnio, Chem. Rec., 2009, 9, 1 .

(22) M. A. Rawashdeh-Omary, M. A. Omary and H. H. Patterson, J. Am. Chem. Soc. 2000, 122, 10371. 